\title{
THE CROWD IN THE LYON COMMUNE AND THE INSURRECTION OF LA GUILLOTIERE
}

Paris and its Commune have so completely dominated historians' accounts of what transpired in France during the spring of 1871 that until the last decade scant attention was paid to the behavior of the provinces. Next to Paris, it was Lyon that produced probably the most significant movement - the Commune of March 22nd-25th and its sequel, the insurrection in the quarter of La Guillotière on April 30th. ${ }^{1}$ In each of these incidents legal proceedings and investigations were begun by the regular judicial authorities, but the Army took over the trial proceedings by virtue of a decree of August 8, 1870, which had placed the Department of the Rhône in a state of siege. The affairs were given separate trials before a conseil de guerre in 1871. Dossiers were compiled on all those individuals killed or ordered arrested in connection with the revolutionary events of March and April and were deposited in the Archives Départementales du Rhône, Series R, under the incident's name and date. There were enough judicial investigations undertaken, and fortunately done in such a thorough manner, that the author found in them the basis for a most fascinating crowd study. ${ }^{2}$

1 For an account of these events see the preceding article by Maurice Moissonnier, and the author's work, "The First International and the Lyon Revolutionary Movement, 1864-1871", unpublished Ph.D. dissertation, University of Wisconsin, 1970.

2 See table. The columns represent the judicial handling of those individuals involved in the revolutionary events in Lyon in March and April, 1871. Beside every column, the column with the letter A represents each category figured as a percentage of the total number of participants. The percentages have not been rounded off. Below is the key to what each column represents.

I. The Lyon Commune of March 22nd through 25th. Persons ordered arrested but not prosecuted: total 17.

II. The Lyon Commune of March 22nd through 25th. Persons ordered arrested and prosecuted: total 50 .

III. A composit of columns I and II : total 67.

IV. The insurrection of La Guillotière. Persons killed : total 21.

V. The insurrection of La Guillotière. Persons wounded and persons ordered arrested but not prosecuted: total 162 .

VI. The insurrection of La Guillotière. Persons ordered arrested and prosecuted: total 156.

VII. A composit of columns IV, V, VI : total 339. 


\begin{tabular}{|c|c|c|c|c|c|}
\hline \multirow{14}{*}{ 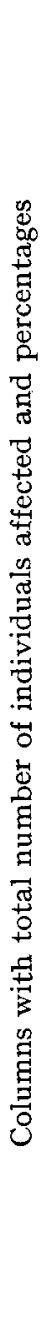 } & $\stackrel{\leftrightarrows}{\Xi}$ & 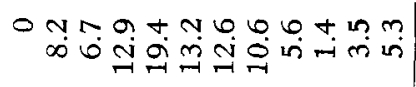 & 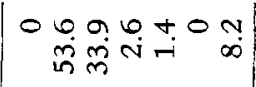 & 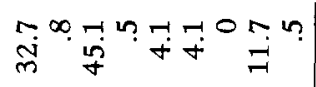 & $\begin{array}{l} \pm 9 \\
\pm \\
+\end{array}$ \\
\hline & ヨ̊ & 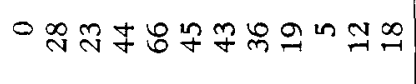 & 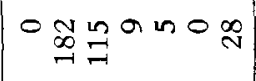 & $\exists m \stackrel{m}{n} N \pm 0 q N$ & 98 \\
\hline & $\stackrel{\unlhd}{\lessgtr}$ & 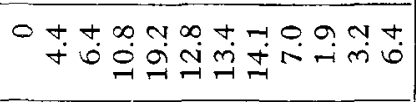 & 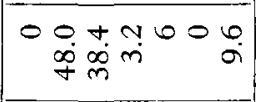 & 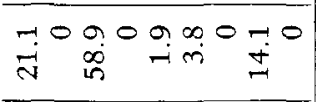 & 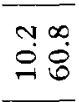 \\
\hline & $\longmapsto \stackrel{0}{\sim}$ & 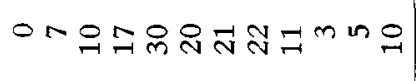 & $0 \ln 8 \ln =\min$ & moNOmbONO & $\stackrel{0}{\circ}$ \\
\hline & $\frac{4}{p}$ & 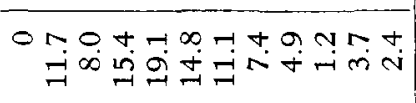 & 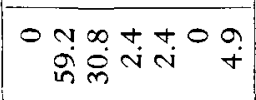 & 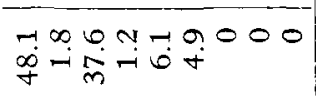 & $\dddot{\vartheta}_{i}^{\infty}$ \\
\hline & $P \underset{N}{\mathbb{N}}$ & 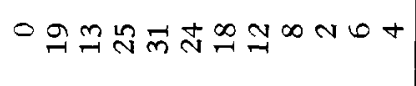 & $\circ \stackrel{0}{\circ}++\infty$ & $\stackrel{\infty}{n} \operatorname{b}^{N} \stackrel{\infty}{\infty} 000$ & $\ddot{m} \stackrel{0}{0}$ \\
\hline & 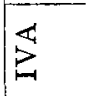 & 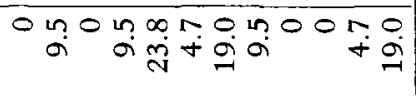 & 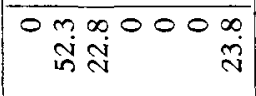 & 0000 Fo & 00 \\
\hline & $\sum \sqrt{2}$ & 0 nonin-7thoont & ofnoogn & $0000-00 \underset{\sim}{N}$ & 00 \\
\hline & $\Xi$ & 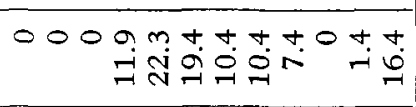 & 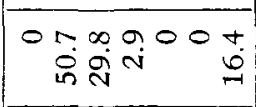 & 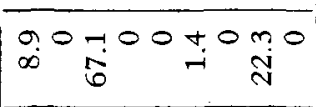 & $0 \underset{N}{\circ}$ \\
\hline & $\exists \sigma$ & 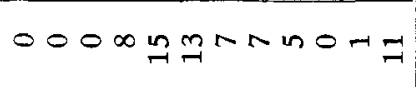 & मั & $00 \ln 00-10 \ln 0$ & $\mathrm{O}_{\mathrm{n}}$ \\
\hline & 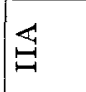 & 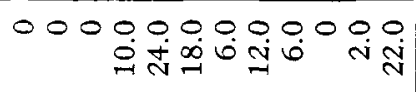 & 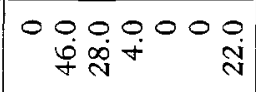 & 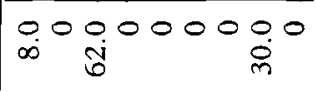 & $0 \stackrel{8}{0}$ \\
\hline & $\bigoplus$ 유 & oo 0 ingmomor & 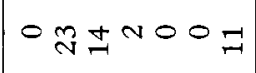 & $+0 \frac{m}{m} 000$ in 0 & $0 \mathrm{~m}$ \\
\hline & $\leftrightarrows$ & 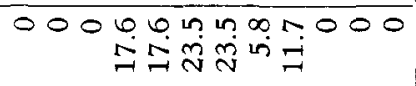 & 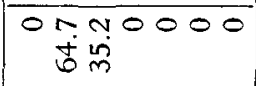 & 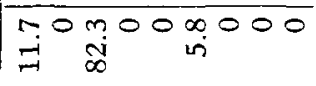 & 8 \\
\hline & $\mapsto \cong$ & $000 \mathrm{mmtH}$ H N 000 & $0=00000$ & NOIOOHOOO & $O \cong$ \\
\hline & 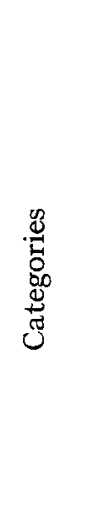 & 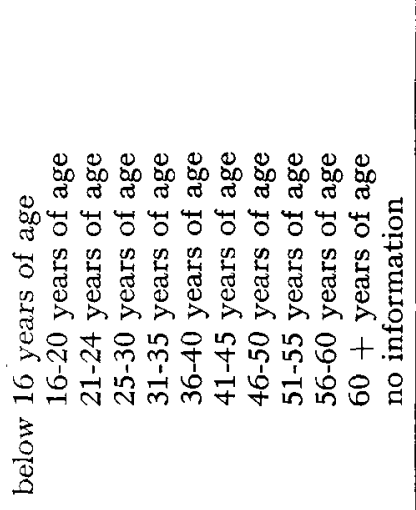 & 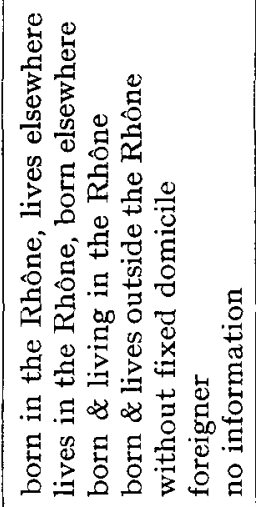 & 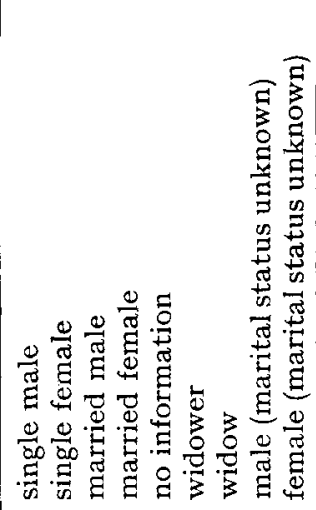 & 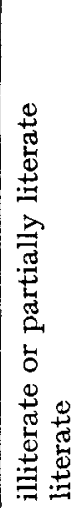 \\
\hline & 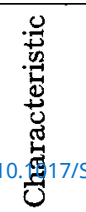 & & 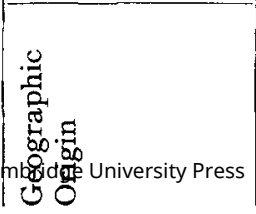 & 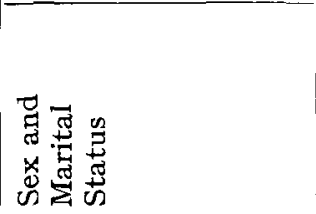 & 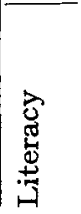 \\
\hline
\end{tabular}


mon ONN-i

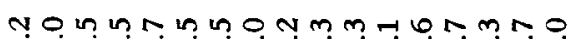
vं

ต ก

\begin{tabular}{|c|c|c|}
\hline Nin $\infty 60$ in $\infty$ & $\infty m a m 0-\pi$ & $0-+\infty N 06 \mathrm{NONN} 06 \infty \mathrm{m}$ \\
\hline
\end{tabular}

○ூ

대 $\quad \infty m$

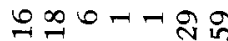

$0 \infty \mathrm{mmo}$

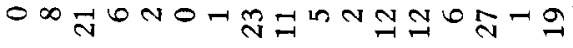

$m$ in $006 \mathrm{~N}$ in in

$\ln +\infty$ N 0 in nरनं

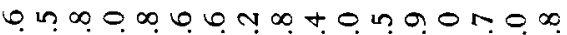

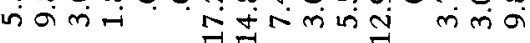
은 $\operatorname{an}$

a 9 in $\rightarrow n$

- a

000000000000 $\stackrel{\circ}{8}$

o OnNMTOONMNONO ino in बंச்

$00000 \frac{4}{4} 000000 \frac{4}{1}$

a tuां十 Ni $\infty$ in

- a ด vin

-

$\stackrel{-1}{0+N}+N$ in in $000 \mathrm{~m}:$

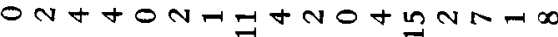

0000000

0.00000

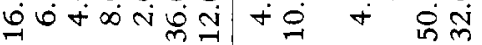

00000000000000000 +

$\infty m \sim+-\infty 0$ Nin 0 no

ONmNONHOMNONm-10 F⿻momon woonomo

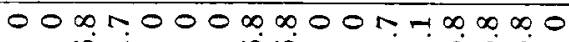

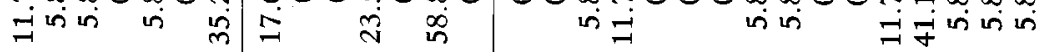

nh-OHO 
The methodological aspect of this particular study was controlled by two factors: information provided in the dossiers and the desire to produce a table that would invite comparison with Jacques Rougerie's work on the Parisian Communards. ${ }^{1}$ A typical background sheet on an individual gives such characteristics as age, place of birth and present residence, marital status and number of children, notation of criminal record, literacy and profession. The categories within each characteristic in the table are those used by Rougerie. Each column represents the judicial handling of the people involved in these two Lyonnaise events, a breakdown which was also used in connection with the Paris survey. Because some columns contain percentages based on data taken from just a few individuals, it would be hazardous to use them to form any firm comparisons between columns. This would be the case even with column III - the total of all those arrested in connection with the Lyon Commune. Columns I-VI are presented, then, so that the reader may draw his own cautious conclusions.

To achieve the most reliable analysis in this crowd survey, it is preferable to use column VII - the total of those individuals implicated for participation in the insurrection of April 30th. The result is that a pattern comes clear quite similar to the one suggested by Rougerie in his examination of the Parisian Communards. ${ }^{2}$ The participants came from the traditional craft industries - shoemaking, textile dying, furniture making, construction - while metal workers, who comprised $15 \%$ of the insurrectionists, represented workers from industries of a more modern type. Only $10 \%$ were silk weavers, which stands in marked contrast with the 1834 uprising in which they accounted for approximately $35 \%$ of the total. ${ }^{3}$ Bourgeois participation was practically nonexistant, comprising slightly less than $2 \%$ of the total. One finds that those with unstable jobs, the day laborers, represent only $5 \%$ of the participants. The insurrectionists, then, were primarily working class individuals skilled in a particular trade.

Only seven women, a little over $2 \%$ of the total, were arrested. Of the males implicated, about one-third of them were single, which roughly corresponds to the ratio in the Department of the Rhone as a whole. ${ }^{4}$ Some $45 \%$ of them were married, usually with a small family of one or two children; whereas, in 1834, two-thirds of those arrested were

1 Jacques Rougerie, Procès des Communards, Paris, Julliard, 1964.

2 Ibid., pp. 125-134.

3 Robert J. Bezucha, "The 'Republican' Insurrection of 1834 in Lyon", Paper read before the meeting of the American Historical Association, Toronto, Canada, December 28, 1967, p. 6.

4 Statistique de la France, Série II, tome XXI, Résultats généraux du dénombrement de 1872, Paris, Imprimerie nationale, 1873, pp. 59-75. 
bachelors. ${ }^{1}$ Over $50 \%$ of the men were in their 30 's and 40 's, while less than $30 \%$ were under 30 . A little more than $8 \%$ were under 20 . The percentage of people in each age category follows a curve that is equivalent to Rougerie's for the Paris Commune. ${ }^{2}$ The category of ages 31-35 contains the largest single percentage $-19.4 \%$, which is very close to Rougerie's $16.6 \%$ for Paris. Rougerie's curve peaked at $17.5 \%$ in the age category 36-40, while in Lyon that category dropped to $13.2 \%$. The Lyon figures should be taken against the background of the Department of the Rhône which reveals a gradual expansion of the male population that reaches its greatest number in the age category 30-35 and then begins to decline. ${ }^{3}$ This is not as sharp a change in percentage in each category as that which is reflected in the figures of those arrested in connection with the April 30th insurrection. The people arrested in Lyon in 1871 were considerably older than those arrested in 1834 , when nearly $70 \%$ of them were under $30 .{ }^{4}$

Scarcely one-third of the participants were born in Lyon or the Department of the Rhône, while about 54\% moved to Lyon from outside the Department. Though the large "no information" category, $8 \%$, tends to undercut the reliability of the comparison, one should note that in Lyon as a whole exactly half of the city's population came from outside the Department. ${ }^{5}$ By contrast, in the Paris Commune $72.6 \%$ of those arrested came from outside the Department of the Seine. ${ }^{6}$ In Lyon, only five people arrested said they had no fixed domicile and just nineteen said they were born and lived outside the Department of the Rhône. Obviously the insurrection was a local affair.

Criminal records were numerous, involving $20 \%$ of those arrested and, surprisingly, almost exactly equal to the percentage for the Paris Commune. ${ }^{7}$ The percentage breakdown of the various categories of crimes in Lyon roughly follows that of Paris. Literacy was quite high, $58.9 \%$, among those arrested in Lyon. The percentage of those who were illiterate or partially literate was close to the average for the entire Department of the Rhône. ${ }^{8}$

Compared to the Lyon insurrectionists of April, 1834, those arrested

1 Bezucha, "The 'Republican' Insurrection”, op. cit., p. 5.

2 Rougerie, Procès, op. cit., p. 125.

3 Statistique de la France, loc. cit.

"Bezucha, "The 'Republican' Insurrection", loc. cit., p. 5.

- Statistique de la France, op. cit., p. 237

- Jacques Rougerie, "Composition d'une population insurgée: la Commune", in: Le Mouvement Social, No 48 (July-September, 1964), p. 35.

7 Rougerie, Procès, op. cit., p. 132.

8 Statistique de la France, op. cit., pp. 42-47. 
in 1871 were older family men, but still moving to Lyon from neighboring departments in search of work. The great contrast between the insurrection of La Guillotière in 1871 and previous revolutionary activity through 1849 that becomes evident as a result of this statistical survey is the marked decline in the participation of the canuts who had been the center of revolutionary activity through $1849 .{ }^{1}$ Perhaps the most plausible explanation is that the canuts were not inherently revolutionary. One can point to the fact that the maitres-tisseurs, because they owned the looms they worked, were petit bourgeois in orientation. This attitude extended to the journeyman who assisted the master and who cherished the hope that one day he too would own his own workshop. In the past, the activism of the canuts had usually coincided with a period of economic stress. 1870-71 happened to be an interval of prosperity for the troubled silk industry and, as well as can be determined, unemployment after the 4th of September struck most acutely at those in the other traditional artisanat occupations. ${ }^{2}$

The insurrection in La Guillotière did not, then, herald the arrival of a new revolutionary proletariat, but was the final revolution of the old milieu just at the inception of its transformation. ${ }^{3}$ It seems now that George Rudé's concept of the 1840's being the watershed between the "pre-industrial" and "industrial" crowds 4 should be altered. The watershed probably belongs after the upheavals of 1870-71.

\footnotetext{
1 A. Latreille et F. Dutacq, Histoire de Lyon, tome III : De 1814 à 1940, éd. A. Kleinclausz, Lyon, Librairie Pierre Masson, 1952, pp. 160-163.

"Jean-Paul Donné, "Une société en crise: La Commune à Lyon 1870-71", unpublished D.E.S., University of Lyon, 1966, makes this conclusion after examining the social composition of those employed in a municipal workshop. 3 This conforms with Jacques Rougerie's interpretation of the Parisian Communards in his Procès, op cit., pp. 128-32.

4 George Rudé, The Crowd in History, 1730-1848, New York, John Wiley and Sons, 1964 , p. 5 .
} 